\title{
The Emerging Role of Epigenetic Mechanisms in the Causation of Aberrant MMP Activity during Human Pathologies and the Use of Medicinal Drugs
}

\author{
Hassan Sarker, Ayman Haimour, Ravneet Toor and Carlos Fernandez-Patron *
}

check for

updates

Citation: Sarker, H.; Haimour, A.; Toor, R.; Fernandez-Patron, C. The Emerging Role of Epigenetic

Mechanisms in the Causation of Aberrant MMP Activity during Human Pathologies and the Use of Medicinal Drugs. Biomolecules 2021, 11, 578. https://doi.org/10.3390/ biom11040578

Academic Editor: Eugene Permyakov

Received: 13 March 2021

Accepted: 14 April 2021

Published: 15 April 2021

Publisher's Note: MDPI stays neutral with regard to jurisdictional claims in published maps and institutional affiliations.

Copyright: (c) 2021 by the authors Licensee MDPI, Basel, Switzerland. This article is an open access article distributed under the terms and conditions of the Creative Commons Attribution (CC BY) license (https:// creativecommons.org/licenses/by/ $4.0 /)$
Department of Biochemistry, Faculty of Medicine and Dentistry, University of Alberta, Edmonton, AB T6G 2H7, Canada; hsarker@ualberta.ca (H.S.); ahaimour@ualberta.ca (A.H.); rktoor@ualberta.ca (R.T.)

* Correspondence: cf2@ualberta.ca

\begin{abstract}
Matrix metalloproteinases (MMPs) cleave extracellular matrix proteins, growth factors, cytokines, and receptors to influence organ development, architecture, function, and the systemic and cell-specific responses to diseases and pharmacological drugs. Conversely, many diseases (such as atherosclerosis, arthritis, bacterial infections (tuberculosis), viral infections (COVID-19), and cancer), cholesterol-lowering drugs (such as statins), and tetracycline-class antibiotics (such as doxycycline) alter MMP activity through transcriptional, translational, and post-translational mechanisms. In this review, we summarize evidence that the aforementioned diseases and drugs exert significant epigenetic pressure on genes encoding MMPs, tissue inhibitors of MMPs, and factors that transcriptionally regulate the expression of MMPs. Our understanding of human pathologies associated with alterations in the proteolytic activity of MMPs must consider that these pathologies and their medicinal treatments may impose epigenetic pressure on the expression of MMP genes. Whether the epigenetic mechanisms affecting the activity of MMPs can be therapeutically targeted warrants further research.
\end{abstract}

Keywords: MMP; epigenetics; cancer; cardiovascular disease; statins; tetracyclines; bone disease; tuberculosis; COVID-19

\section{Introduction}

Matrix metalloproteinases (MMPs) are a family of at least 23 different $\mathrm{Zn}^{2+}$-containing endopeptidases whose abnormal expression contributes to many disorders, including pathological tissue remodeling, arthritis, cancer, and inflammation [1]. MMPs are regulated at the transcriptional, translational, and post-translational levels, as well as by interactions with tissue inhibitors (TIMPs) and acute phase reactants in the circulation $(\alpha 2-$ macroglobulin, fibrinogen), which define states of MMP overactivity or underactivity $[1,2]$.

The transcriptional regulation of MMP activity involves transcription factors, DNA polymorphisms, and promoter/enhancer elements, and epigenetic mechanisms, which are the focus of this review. The concept of epigenesis finds its origin in the scientific debate regarding processes that drive development in cells, proposing that chemical reactions involving soluble cellular components can influence cell development [3]. With our increased understanding of chromosomes and DNA, the concept of epigenesis has evolved. Currently, epigenetics builds on the notion that all somatic cells in an organism contain the same DNA, with different cell types exhibiting different patterns of gene expression that can be clonally inherited [3]. Quantifiable epigenetic mechanisms of gene regulation involve chemical modifications on DNA (such as methylation) and DNA-bound histone proteins (such as methylation or acetylation of histone tails) [3].

Chemical modifications of DNA and histones regulate gene expression by impacting the extent of DNA compaction and therefore the accessibility of transcriptional machinery to genes $[4,5]$. DNA compaction into chromatin is achieved through the interaction of DNA 
with an octamer of the core histones [4,5]. This octamer consists of two of each of the histone proteins $\mathrm{H} 2 \mathrm{~A}, \mathrm{H} 2 \mathrm{~B}, \mathrm{H} 3$, and $\mathrm{H} 4$, with approximately 146bp of DNA wrapped around the octamer, forming the nucleosome core particle [4,5] (Figure 1). Multiple nucleosome core particles are connected via linker DNA and the associated linker histone H1 $[4,5]$. The $\mathrm{N}$-terminal tails of core histones are accessible to post-translational modifications, which can influence gene expression by facilitating or hindering the access of transcription factors and enzymes to the DNA promoter regions [6-8] (Figure 1). These modifications include but are not limited to methylation, acetylation, and phosphorylation [9]. In addition to DNA methylation, histone modifications are heritable changes that alter gene expression but not the DNA sequence of genes [9]. Such epigenetic modifications are mediated by DNA methyltransferases, histone acetylases (HATs), histone deacetylases (HDACs), and histone demethylases (HDMs) [9-13] and through the interaction of small non-coding RNA, such as microRNAs and small-interfering RNAs with their corresponding target mRNA, results in gene silencing effects by way of mRNA degradation or transcriptional repression [9,14] (Figure 1). Multiple miRNAs with potential regulatory effects on MMPs have been identified [15], some of which have been confirmed experimentally, which are further discussed here.

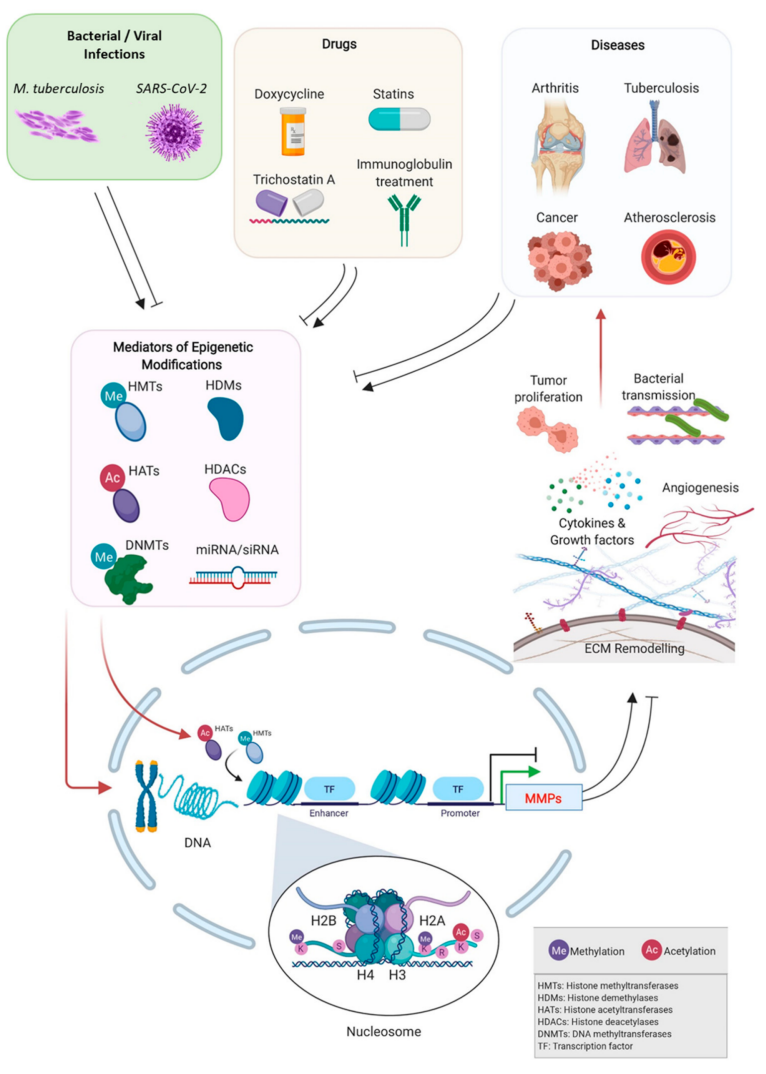

Figure 1. A summary map of the epigenetic regulation of matrix metalloproteinases (MMPs). The epigenetic pressure inducers affecting MMP genes include (i) pathological mechanisms underlying chronic diseases, and (ii) drugs commonly used in treatments for chronic diseases. Epigenetic modifications on DNA, histones, and expression of miRNAs result in dysregulation of the gene expression of MMP, which leads to (i) further promotion of the pathogenesis of an existing disease, and (ii) initiating abnormal remodeling of the extracellular matrix and the regulation of other MMP targets.

Here, we review the current evidence of epigenetic regulation of MMP expression in human diseases including atherosclerosis, arthritis, bacterial infection (tuberculosis), viral infection (COVID-19), and cancer. We also examine evidence of the epigenetic regulation of MMP expression in response to commonly prescribed medicinal drugs with known, 
but poorly understood, MMP modulatory actions such as statins, which exert epigenetic pressure on many genes and inhibit MMP secretion [16-18], and the antibiotic doxycycline, which reduces MMP activity and gene expression $[19,20]$. The possible involvement of epigenetic mechanisms in the causation of aberrant MMP activity in the settings of acute and chronic diseases and in response to common medicinal drugs is important for predicting disease development and progression, as well as for designing more efficacious therapeutic interventions.

\section{Epigenetic Regulation of MMPs Expression in Physiological Conditions}

Varied gene expression patterns of MMP family members across different cell types may be caused by the cell-type-specific expression of transcription factors and polymorphisms in the promoters of MMP genes, in addition to DNA methylation and histone modifications [21].

The promoter regions of at least fourteen MMP genes (MMP-1, $-2,-9,-11,-14$, $-15,-16,-17,-21,-23,-24,-25,-26$, and -28 ) and all four tissue inhibitors of metalloproteinases (TIMP-1, $-2,-3$ and -4 ) contain CpG islands that are prone to DNA methylation by DNA methyltransferases [22,23]. DNA methylation generally induces gene repression by preventing transcription factor binding or by attracting methyl-CpG binding proteins that are transcriptional repressive $[9,10]$. 5-aza-2'-deoxycytidine, a DNA methyltransferase inhibitor, reversed hypermethylation at the $M M P 9$ promoter (hypermethylation of a promoter represses gene transcription) and concomitantly induced MMP9 gene expression in lymphoma cell lines [24]. MMP1 expression is silenced by the methylation of a single CpG site that can be rescued by 5-aza-2'-deoxycytidine [23]. In the colon cancer cell line HCT 116, the deletion of the DNA methyltransferases Dmt-1 and Dmt3b and treatment with demethylating agents induced $M M P 3$ gene expression without affecting MMP1 or MMP2 [25]. Treatment of human non-Hodgkins Raji B lymphoma cells with the demethylating agent 5-aza-2'-deoxycytidine did not induce MMP3 expression, but instead concentration-dependently increased MMP10 transcription [25]. These studies suggest that the methylation of $\mathrm{CpG}$ sites is a mechanism of MMP gene regulation at the level of transcription, and that DNA methylation/demethylation alters MMP gene transcription in a cell-specific fashion.

Histone-modifying enzymes that introduce chemical modifications on histone tails, particularly $\mathrm{H} 3 / \mathrm{H} 4$ acetylation, methylation, or phosphorylation, work alongside chromatinremodeling complexes to impose control on gene expression by modulating chromatin structures and the accessibility of gene promoters [26,27]. Histone deacetylase 2 and chromatin-remodeling enzyme Mi-2, when recruited to the MMP9 promoter, reduce $\mathrm{H} 3 / \mathrm{H} 4$ acetylation levels and DNA accessibility, consequently repressing MMP9 gene expression [28]. Similar transcriptional control via histone modifications and chromatin remodeling has been observed for $M M P-1,-10$, and $-13[29,30]$. Our understanding of the role played by DNA methylation and histone modifications in regulating the network of MMPs that maintain extracellular matrix homeostasis remains unclear, but it has increased through studies of disease conditions.

\section{Epigenetic Regulation of MMPs Expression in Pathological Conditions}

\subsection{Cancer}

MMPs promote cancer progression through distinct mechanisms, including (i) activation of growth factors [31], (ii) interference with apoptosis pathways [32], (iii) promoting the growth of tumor vasculature [33], and (iv) promoting tissue invasion and metastasis [34]. The last decade has provided mounting evidence that the epigenetic regulation of MMP genes contributes to cancer progression. Strongin et al. demonstrated that the proinvasive MT1-MMP/MMP-2/TIMP-2 axis is epigenetically regulated in cancer cells [35]. Low migratory breast carcinoma MCF-7 cells exhibited epigenetic transcriptional silencing of MT1-MMP and MMP-2 via the hypermethylation of CpG sites in their respective gene promoters and histone $\mathrm{H} 3$ lysine-27-trimethylation. In contrast, highly migratory 
glioblastoma cells exhibited hypomethylation of CpG sites and low levels of $\mathrm{H} 3$ lysine-27trimethylation [35]. Corroborating these results, DNA methyltransferase inhibition with 5-aza-2'-deoxycytidine increased the transcription of MT1-MMP and MMP2 in pancreatic cancer cells, thereby increasing their invasiveness [36]. In breast cancer cell lines, MCF-7 and MDA-MB-436, 5-aza-2'-deoxycytidine induced the demethylation of CpG sites in the MMP9 promoter and histone $\mathrm{H} 3$ lysine-4-trimethylation (an epigenetic marker of open chromatin-allowing gene transcription) [12], resulting in increased MMP9 expression [37]. Further, treatment of urothelial cancer cell lines with 5-aza-2'-deoxycytidine or trichostatin A (histone deacetylase inhibitor) induced transcription of $22 \mathrm{MMPs}$ and promoted cancer cell proliferation, migration, and invasion [38]. In glioblastoma cell lines, the expression of microRNAs targeting DNA methyltransferases induced MMP2 and MMP9 expression [39]. MMP gene expression can be dysregulated in cancer cells indirectly via epigenetic control of GRK6. This gene encodes G protein-coupled receptor kinase 6 (GRK6), an enzyme involved in repressing angiogenesis, tumor growth, and metastasis [40]. GRK6 decreases the expression of the cancer-promoting genes $M M P 2$ and $M M P 7$ [41]. In lung adenocarcinoma cells, the GRK6 promoter is hypermethylated and GRK6 expression is repressed, which promotes cell migration and invasion [41]. Thus, ablation of the GRK6-mediated repression of MMP-2 and MMP-7 may increase the invasiveness of lung adenocarcinoma cells.

Cock-Rada et al. (2012) showed that H3K4 methyltransferase SMYD3 epigenetically regulates the transcription of the MMP9 gene in a fibrosarcoma cell line (HT1080) and B-cell lymphosarcoma cell line (TBL3) infected with T. annulata [42]. Increased MMP9 mRNA levels in TBL3 cells were associated with greater H3K4me2 and H3K4me3 marks in the regulatory region of the $M M P 9$ promoter. The elevated histone marks were determined to be the result of SMYD3, as it was the only methyltransferase significantly induced in TBL3 cells. SMYD3 induces transcriptional activation by binding to the $5^{\prime}$-CCCTCC-3' or $5^{\prime}$-GGAGGG-3' DNA sequences in the promoter region of genes including MMP9. Furthermore, HT1080 cells transfected with siRNAs against SMYD3 resulted in decreased cell migration and proliferation accompanied by decreased levels of MMP9 mRNA and protein. Similar results were achieved by knocking down only MMP-9. Therefore, SMYD3 acts as an epigenetic regulator of $M M P 9$, and consequently affects cancer invasion.

MMP9 has also been reported to be the target of miR-211 [43]. In multiformed grade IV glioblastoma specimens, miR-211 expression is suppressed as a result of abnormal methylation of its promoter [43]. An inverse relationship between the expression of miR211 and MMP-9 protein levels was observed. Asuthkar et al. (2012) also showed that miR-211 overexpression and shRNA specific for MMP9 (pM) treatments was associated with anti-proliferative and apoptotic signaling in 4910 cancer stem cells and U87 glioma cells. Following treatment, an increase in the cleaved $35 \mathrm{kDa}$ fragment of Caspase- 9 was observed, which was indicative of Caspase- 9 activation. This then triggered pro-apoptotic pathways following the effector caspase cleavage and activation. The overexpression of miR-211 also inhibits glioma cell invasion and migration via suppressing MMP9 expression. Other known targets of miRNAs in cancers include $M M P 2, M M P 9, M M P 13, M M P 14$, and MMP16 and their substrates such as type I, II, and IV collagens [22,23].

\subsection{Cardiovascular Diseases}

Aberrant activity of MMPs contributes to the development and progression of atherosclerosis by influencing the local inflammatory response at the site of atherosclerosis plaque formation and by catalyzing plaque rupture, an event that ultimately culminates in myocardial infarction and heart failure [44]. Recent evidence implicates epigenetic control of MMP expression in multiple cardiovascular pathologies, including atherosclerosis. The induced hypomethylation of $M M P 2$ and $M M P 9$ via microRNA-29b upregulation is a mechanism by which oxidized low-density lipoprotein (oxLDL) contributes to atherosclerosis [45]. The oxLDL promotes atherosclerotic plaque formation by inducing smooth muscle cell migration and proliferation. In human aortic SMC, oxLDL induced cell migration via the upregulated expression and activation of MMP-2 and MMP-9 due to the fact that both 
MMPs promote smooth muscle cell migration [46]. Analysis of the DNA methylation status of MMP2 and MMP9 following oxLDL treatment revealed significant demethylation in the two genes [45]. DNMT3b mRNA and protein levels in human aortic SMCs significantly decreased after oxLDL treatment [45]. DNMT3b knockdown in oxLDL-treated human aortic SMCs significantly increased MMP2 and MMP9 mRNA levels, indicating that MMP2 and MMP9 were repressed by DNA methylation. These results show that upregulated MMP2 and MMP9 expression resulted from decreased DNA methylation due to DNMT3b downregulation. Further, Chen et al. (2011) also determined that microRNA-29b was upregulated in a dose-and time-dependent manner in oxLDL treated SMCs [45]. These results suggest that microRNA-29b indirectly modulates the DNA methylation of MMP2 and MMP9, and thus their expression, by regulating the expression of DNMT3b.

Thus, DNA methylation leading to aberrant expression of MMPs can significantly influence the progression and development of cardiovascular diseases. Similarly, the hypomethylation of the MMP9 gene and the aberrant upregulation of MMP9 expression is observed in Kawasaki disease, a pediatric vascular disease characterized by inflammation of the coronary arteries [47]. The methylation status of the CpG sites of MMP9 shows a strong negative correlation with mRNA expression levels, indicating that MMP9 is repressed by DNA methylation [47]. Furthermore, a differential methylation status in all MMP genes was induced by intravenous immunoglobulin treatment in Kawasaki disease patients [47] (Figure 1).

\subsection{Bone/Cartilage Diseases}

MMPs modulate bone growth, development, and repair processes through their actions on extracellular matrix components, and dysregulated MMP expression and activity are thus implicated in bone diseases such as osteoarthritis (OA) and rheumatoid arthritis [48] (Figure 1). A genome-wide analysis of DNA methylation status involving osteoarthritis patients found the MMP3, MMP9, and MMP13 genes to be hypomethylated (with increased gene expression) in osteoarthritis versus non-osteoarthritis chondrocytes $[49,50]$. The percentage of methylated CpG sites of these MMP genes in clonal chondrocytes from osteoarthritis patients versus controls were: $80 \%$ versus $96 \%$ for MMP13, $19 \%$ versus $53 \%$ for $M M P 9$, and $43 \%$ versus $70 \%$ for MMP3 [50]. The study concluded that the altered expression of cartilage-degrading MMPs resulted from clonally heritable epigenetic changes that may exacerbate osteoarthritis.

MicroRNA-222 and microRNA-27b regulate MMP13 expression in osteoarthritis chondrocytes [51]. Song et al. (2015) found that miR-222 expression is downregulated and its target HDAC-4 is consequently upregulated in OA chondrocytes [51]. Elevated HDAC-4 expression thereby increased MMP13 expression via histone de-acetylation. The study also showed that the inhibition of HDACs by Trichostatin A (TSA) lowered the HDAC-4 and MMP-13 protein expression in OA chondrocytes, thereby confirming the role of HDAC-4 in regulating MMP-13. When overexpressed, MMP-13 can exacerbate OA [52]. Akhtar et al. (2010) found a direct inhibitory effect of miR-27b on the expression of the MMP13 gene in the OA chondrocytes [52]. MicroRNA miR-27b interacts with the $3^{\prime}$-untranslated region of MMP13 mRNA, which contains a complementary sequence to the miR-27b seed sequence and downregulates MMP13 expression at the post-transcriptional level [52]. MiR-27b expression was found to be significantly reduced in OA cartilage when compared to normal cartilage. OA chondrocytes exhibiting higher levels of miR-27b produced significantly less MMP-13 protein upon IL-1 $\beta$ stimulation compared to chondrocytes that were not transfected with a miR-27b mimic, and inhibition of miR-27b increased MMP-13 protein expression in IL- $1 \beta$-stimulated chondrocytes when compared to control OA chondrocytes. These findings indicate that $\mathrm{miR}-27 \mathrm{~b}$ acts as a regulator of MMP-13 protein expression in human OA chondrocytes [52].

In rheumatoid arthritis (RA), abnormal histone modifications and DNA methylation both lead to aberrant upregulation of MMP gene transcription [53] (Figure 1). Genome-wide DNA hypomethylation is observed in rheumatoid arthritis synovial fibroblasts (RASF), 
resulting in the upregulated expression of 186 genes including MMP1 and MMP14 [54]. In RASF, histone H3 lysine-4-trimethylation (the histone marker for active transcription) is increased, while transcription-repressive H3 lysine-27-trimethylation is decreased in the promoters of $M M P 1, M M P 3, M M P 9$, and MMP13 [55]. Interestingly, despite increased active histone markers in its promoter, $M M P 9$ expression was not upregulated by interleukin6 (IL-6) induction, while MMP1, MMP3, and MMP13 were upregulated. This occurs as a result of the IL-6-inducible transcription factor STAT3 being recruited to the promoters of $M M P 1, M M P 3$, and $M M P 13$, but not to the MMP9 promoter [55]. The differential expression of MMP genes with similar histone methylation states suggests that epigenetic mechanisms work in concert with the canonical mechanisms of MMP transcription control.

Furthermore, recent evidence suggests that MMP9 expression in RA may also be epigenetically regulated by miRNAs. Wang et al. (2019) reported that the fibroblastlike synoviocytes from patients with RA exhibited elevated miR-145-5p expression and increased MMP9 mRNA and protein levels [56]. The overexpression of miR-145-5p induced the nuclear translocation of p65, thereby activating NF- $\mathrm{B}$ which induced the expression of $M M P 9$ by binding the MMP9 promoter region [56]. These demonstrate that miR-145-5p can indirectly modulate the expression of MMP9 in patients with RA [56].

\subsection{Bacterial Infections-Tuberculosis}

Epigenetic regulation of MMP-1 and MMP-3 (a physiological MMP-1 activator) modulates the immune response against Mycobacterium tuberculosis (Mtb) in pulmonary tuberculosis [57-60]. In a study by Moores et al. (2017), Mtb infection decreased gene expression of class I histone deacetylases (HDACs 1, 2, 3, and 8) by more than 55\% in human Mtb-infected macrophages [57]. No significant decrease in the gene expression of class I HDACs was seen in normal human bronchial epithelial (NHBE) cells stimulated with conditioned medium from Mtb-infected monocytes (CoMTb) [57]. The inhibition of HDACs (with trichostatin A and $\mathrm{m}$-carboxycinnamic acid bis-hydroxamide) reduced MMP-1 and MMP-3 secretion in Mtb-infected macrophages and CoMTb-stimulated NHBEs [57]. However, the HDAC class I-specific inhibitor, MS-275, increased MMP-1 and MMP-3 secretion in CoMTb-stimulated NHBEs while decreasing MMP-1/-3 secretion in Mtb-infected macrophages [57]. Therefore, altered histone acetylation in Mtb infection may affect MMP-1/-3 expression. The study also showed that inhibition of histone acetyltransferases (HATs), using HATi II, lowered MMP-1 expression and secretion by more than $50 \%$ as well as significantly lower MMP-3 secretion in Mtb-infected macrophages [57]. HAT inhibition was also confirmed using another HAT inhibitor, anacardic acid, which significantly lowered MMP-1 and MMP-3 secretion in Mtb-infected macrophages [57]. These results indicate that acetylation by HATs is needed for MMP-1 and MMP-3 expression and secretion in Mtb-infected cells. Moreover, an increased histone $\mathrm{H} 3$ and $\mathrm{H} 4$ acetylation of the $M M P 1$ promoter region was reported in CoMTb-stimulated NHBEs compared to the uninfected controls. This accompanied a more-than-10 fold increase in RNA polymerase II binding to the MMP1 promoter [57]. These results suggest that the epigenetic modification in the promoter region induced by Mtb infection can alter MMP1 gene expression.

The effects of HDACs and HATs on MMP expression can be more complex and indirect, due to interrelated signaling cascades involving transcription factors and nonhistone proteins that can also be substrates of the above-mentioned enzymes [61-63]. Such non-histone substrates include HDACs themselves [63], in addition to the NF- $k \mathrm{~B}$ and AP-1 family of transcription factors, which are believed to regulate MMP1 gene expression $[60,64]$. To further demonstrate the role of non-histone proteins in mediating the regulation of HDAC on MMP expression, Liu et al. (2003) reported that upregulation of the reversion-inducing-cysteine-rich protein with kazal motifs (RECK), a reported tumor invasion and angiogenesis suppressor [65], induced by HDAC inhibition downregulates the activation of MMP-2 [66]. The HDAC inhibitor trichostatin A upregulated RECK gene expression in CL-1 human lung cancer cells [66]. Trichostatin A-treated CL-1 cells exhibited inhibition of MMP-2 activity. This was not caused by the downregulation 
of MMP2 gene expression, but rather the downstream effects of trichostatin A-induced RECK upregulation, which decreased CL-1 cancer cell invasion [66]. The results were confirmed using siRNA to suppress RECK expression, which restored the trichostatin A-induced inhibition of MMP-2 activity [66]. Barchowsky et al. (2000) reported the involvement of the inflammatory cytokine IL-1 in the activation of MMP1 gene expression in rabbit primary synovial fibroblasts (RSF) [64]. The activation of MMP transcription by IL-1 is mediated through the NF- $\kappa$ B pathway [64]. In addition to IL-1, TNF- $\alpha$ can also induce gene expression of MMPs, such as the MMP1 and MMP13 genes, via downstream phosphorylation pathways $[67,68]$. These pathways include the NF- $\mathrm{B}$ B and the mitogenactivated protein kinase (MAPK) pathways, and the MAPK pathway can, in turn, activate downstream transcription factors such as AP-1 and induce MMP expression along with NF- $\mathrm{BB}$ in a parallel pathway $[67,68]$. Interestingly, the network between the mediators of signaling pathways and epigenetic changes has revealed an interaction between HDAC-1 and the NF- $\kappa$ B subunit p65 (RelA) that in turn suppresses the expression of NF- $\mathrm{B}$-regulated genes [69], which can include MMPs. Therefore, the involvement of the phosphorylation pathways and the subsequent involvement of transcription factors may explain the indirect effect of HDAC inhibition on MMP1 expression, as reported in tuberculosis and the cytokine-induced expression of MMP-1/-13 proteins in human articular chondrocytes. The relationship between HDAC/HATs activity and MMP expression and activity is influenced by determinants of inflammatory status such as the levels of pro-inflammatory cytokines (e.g., IL-1 and TNF- $\alpha$ ) and transcription factors (e.g., AP-1 and NF- $\mathrm{B}$ ).

To further delve into examples of cytokine-mediated intermediary signaling pathways, Mittelstadt and Patel (2012) reported the inhibitory effect of the anti-proliferative cytokine interferon- $\beta$ (IFN- $\beta$ ), on MMP9 gene expression in human HT1080 fibrosarcoma cells [70]. IFN- $\beta$ decreased NF- $\kappa$ B recruitment, however, it increased HDAC-1 recruitment to the promoter-proximal AP-1 site of $M M P 9$, subsequently reducing histone $\mathrm{H} 3$ acetylation [70]. IFN- $\beta$-induced post-translational modifications of the transcription factor AP-1 repolarized its role from being pro-transcription to anti-transcription, which may be facilitated by its increased binding to and recruitment of HDAC-1 [70]. Therefore, such inhibition of MMP9 expression could reduce its pro-angiongenic, inflammatory, and metastatic roles (Figure 1), and thus alter its extensive involvement in infections and auto-immune diseases such as arthritis, lupus, and multiple sclerosis [70-72].

MMPs can contribute to infection-induced endotoxic shock through their altered expression in the disease state, in which they modulate the secretion of inflammatory cytokines and degrade the proteins of the endothelial basement membrane, such as type IV collagen [73]. Such cleavage of the basement membrane proteins facilitates the dissemination of pathogens to distant organs and results in systemic endotoxic shock [73]. The expression of several MMPs in macrophages, including MMP-1, -7, and -9, can be induced in infection states via inflammatory stimuli such as bacterial lipopolysaccharides (LPS) [74]. In bone marrow-derived macrophages (BMM), bacterial LPS induced the expression of the HDACs 1, 4, 5, and 7 [75]. In addition, LPS induced HDAC-2 expression in macrophages, accompanied by a pro-inflammatory immune response [75]. Therefore, the expression of MMPs, such as MMP-1 and/or MMP-9, can be epigenetically regulated in multiple diseases influenced by HDACs, as mentioned previously, including inflammatory conditions such as rheumatoid arthritis, bacterial infections, and cancer metastasis. Considering the overall interplay between the phosphorylation signaling pathways, inflammatory cytokines, and mediators of epigenetic changes, the expression of MMPs can be altered indirectly, on both the genetic and epigenetic levels, consequently exacerbating the pathogenesis of these diseases.

\subsection{Viral Infections}

Multiple viruses including the hepatitis $C$ virus (HCV), the middle east respiratory syndrome coronavirus (MERS-CoV), and H5N1 avian influenza (HPAI) impact the epigenetic regulatory mechanisms in the genome of the host cell [76-78]. HCV via its core 
protein can interfere with $\mathrm{H}_{2} \mathrm{O}_{2}$ (a reactive oxygen species)-induced apoptosis in human hepatocytes through the p53-dependent pathway by epigenetically inhibiting its modulator p14 [76]. The core protein of HCV inhibits p14 expression via inducing hypermethylation of its promoter region, consequently downregulating p53 levels [76]. Coronaviruses, such as MERS-CoV, and influenza viruses, such as HPAI, downregulate the antiviral interferon (IFN)-stimulated genes by inducing inhibitory histone methylations [77]. Furthermore, MERS-CoV, through DNA methylation, and H5N1-VN1203, through both DNA methylation and histone modifications, antagonize host gene expression of IFN- $\gamma$-related antigen-presentation-associated genes [78]. On the other hand, H1N1-09 and severe acute respiratory syndrome coronavirus (SARS-CoV) infections resulted mostly in the strong upregulation of IFN- $\gamma$-responsive genes [78].

Likewise, the highly infective severe acute respiratory syndrome coronavirus 2 (SARSCoV-2), the causative agent of coronavirus disease-19 (COVID-19), also impacts the host's epigenome environment [79]. The entry of the SARS-CoV-2 into the host's cell relies on how the viral spike (S) glycoprotein interacts with the host cell receptor, angiotensin-converting enzyme 2 (ACE2) receptor, accompanied by $S$ protein priming mediated by the cellular serine protease TMPRSS2, which cleaves the $S$ protein [80]. SARS-CoV-2 infection induces oxidative stress, which aggravates epigenetic changes such as the DNA hypomethylation of the ACE2 gene, leading to ACE2 overexpression, which may further increase the susceptibility of host cells to SARS-CoV-2 infection [81]. In a recent report, SARS-CoV-2 infection resulting in severe COVID-19 was associated with changes in genome-wide DNA methylation in peripheral blood mononuclear cells, and comparing severe COVID-19 versus uninfected controls identified 40,904 differentially methylated loci, whereas COVID-19 versus influenza identified 26,733 differentially methylation loci [82]. In severe COVID-19 cases, the gene of the transcription factor STAT3, which binds to the promoters of MMP1, $M M P 3$, and MMP13 [55] and regulates their expression, had eight hypermethylated CpG sites, which indicates an epigenetic inhibition of STAT3 expression [82]. Circulating MMP-9 is elevated in severe COVID-19, although the mechanism of this upregulation is unclear [83]. These data show that viral infections such as SARS-CoV-2 can induce genome-wide epigenetic changes in host cells, and could thus potentially affect the expression of the MMPs that play important roles in the pathogenesis of acute respiratory distress syndrome through the degradation and remodeling of the lung extracellular matrix $[82,84,85]$.

\section{Pharmacologically Induced Epigenetic Control of MMPs}

\subsection{Epigenetic-Based Therapeutic Control of MMPs and Mediators of Epigenetic Changes}

Elucidating the epigenetic mechanisms involved in chronic diseases and infections can be critical not only to understand the pathogenesis mechanisms of these diseases but also to design novel therapeutic interventions. For instance, in tuberculosis, the inhibition of HDACs using suberanilohydroxamic acid (SAHA), also known as the drug Vorinostat, resulted in an immune response by macrophages and subsequently $\mathrm{T}$ cells against Mtb [86]. This immune response involved increased production of IL-1 $\beta$ and reduction of IL-10, accompanied by stimulation of $\mathrm{T}$ cells in a human $\mathrm{Mtb}$-infected macrophage culture system [86]. Furthermore, in water-borne parasitic infections by Cryptosporidium species (causing cryptosporidiosis) such as C. parvum, Vorinostat showed anti-parasitic in vitro and in vivo potential by targeting the HDAC of C. parvum [87]. Furthermore, in human articular chondrocytes, fibroblast growth factor- 2 along with IL- $1 \beta$-induced expression of MMP-1/-13 can lead to cartilage degradation [88]. However, upon HDAC inhibition using trichostatin A (TSA), the induced expression of these MMPs was decreased [88]. Therefore, our understanding of these inflammatory pathways and their relationships to the expression of MMPs is essential in therapeutic designs based on the epigeneticmediated inhibition of MMP expression. For instance, Young et al. (2005) reported the favorable effects of the HDAC inhibitors trichostatin A and sodium butyrate in reducing cartilage degradation mediated by the pro-inflammatory cytokines-induced expression of MMP-1/-13 [30]. 
The MMP-2-mediated degradation of the extracellular matrix (ECM) in periodontitis can be epigenetically induced by the spirochete T. denticola [89]. During the T. denticola challenge of periodontal ligament (PDL) cells, the induced expression of the MMP2 gene was reversed with HDAC inhibition treatment using apicidin and trichostatin $\mathrm{A}$, in addition to inhibitors of histone phosphorylases and DNA methyltransferases [89]. Thus, treatment strategies involving HDAC-inhibiting drugs are successful candidates for managing rheumatoid arthritis and possibly bacterial infections, which highlights the importance of investigating the inhibition of other mediators of epigenetic modifications affecting MMP expression in infections and other diseases.

\subsection{Statins}

MMP gene expression is altered at the transcriptional and post-transcriptional levels by statins [16,17], a family of commonly prescribed drugs for lowering plasma low-density lipoprotein cholesterol levels [90]. Statins induce epigenetic changes on the genes involved in atherosclerosis development, cell-cycle progression, and tumorigenesis [18,91-94]. Increased histone acetylation through the inhibition of HDACs is an anti-cancer therapeutic strategy $[95,96]$. Atorvastatin, fluvastatin, lovastatin, pravastatin, and simvastatin inhibited HDAC activity and increased acetylation levels of histone H3 in human A549 lung carcinoma cells [94]. These statins increased the mRNA expression of p21, a cyclin-dependent kinase inhibitor, by inducing HDAC 1 and 2 removal and allowing for increased histone $\mathrm{H} 3$ acetylation at the $p 21$ promoter [94]. The increased p21 expression resulted in inhibition of tumor proliferation [94]. DNA hypermethylation and inactivation of tumor suppressor genes is a therapeutic target in tumor formation [97]. Karlic et al., (2015) reported the downstream epigenetic effects of statins, in which simvastatin induced downregulation of DNA methyltransferases in human cancer cell lines including ovarian cancer, breast cancer, prostate cancer, and osteosarcoma [92]. Furthermore, simvastatin induced the downregulation of HDAC-1, -2, -3, -7, and -8 mRNA expression [92]. Thus, statins exert downstream anti-cancer potential through epigenetic modifications [91,92,94] mediated by the common epigenetic regulators of MMPs.

The epigenetic effects of rosuvastatin, atorvastatin, and lovastatin are involved in atherosclerosis regression, where they induce the mRNA expression of the chemokine receptor CCR7 in mice RAW264.7 macrophages [93]. Rosuvastatin induces CCR7 expression partly by releasing class II HDACs from the CCR7 promoter region and increasing histone $\mathrm{H} 3$ and $\mathrm{H} 4$ acetylation to the same region [93]. Consequently, rosuvastatin induces plaque regression through the removal of macrophages from atherosclerotic plaque, which is mediated by CCR7 activation [93].

Atorvastatin, Fluvastatin, and simvastatin show impacts on MMP gene expression [17, $98,99]$. They inhibited MMP-1 and MMP-3 secretion from naïve and cytokine-stimulated human fetal lung fibroblasts [98].

Treatment of human vascular endothelial cells with fluvastatin and lovastatin inhibited the expression of MMP-1, but not the expression of the tissue inhibitor of MMP-1 [99]. Fluvastatin reduced MMP-9 secretion and activity from mouse macrophages [100]. Lovastatin and cerivastatin inhibited the secretion of MMP-1, -2, -3, and -9 in human vascular smooth muscle cells [17]. Simvastatin inhibited MMP-9 expression in rat alveolar macrophages exposed to cigarette smoke extract [101]. Conceivably, long-term treatment with statins is likely to alter the transcriptional control of many MMP genes involved in atherosclerosis, a hypothesis that warrants investigation.

\subsection{Tetracyclines with MMP Inhibitory Actions}

Tetracyclines exert antibiotic effects by binding to bacterial $30 S$ ribosomal subunits to inhibit bacterial protein synthesis [19]. In addition to their antimicrobial use, some tetracyclines (e.g., minocycline and doxycycline) exhibit MMP-inhibitory properties [102-105] through their ability to: (i) bind metal ions required for the catalytic activity of MMPs [102], and (ii) inhibit MMP gene transcription [103-105]. Doxycycline, the tetracycline with 
the strongest MMP inhibitory actions [102], has been approved as an MMP inhibitor by various regulatory bodies, including Health Canada and the U.S. FDA, for the treatment of periodontitis and rosacea. No other MMP inhibitor has received FDA approval for treating human disorders, largely because, in early trials, various MMP inhibitor structures caused major adverse effects including increased mortality in cancer patients [106]. Interestingly, in the recent TIPTOP trial [107], low-dose doxycycline (100 mg b.i.d. for 7 days) reduced left-ventricular hypertrophy and dysfunction in patients with acute and severe myocardial infarction. Based on these promising results, two new trials were approved to explore the application of doxycycline in myocardial infarct patients in Australia (ACTRN12618000467235) and Canada (ClinicalTrials.gov Identifier: NCT03508232). Whether MMP inhibition or the epigenetic mechanisms leading to decreased MMP activity underlie the benefits of doxycycline in these cardiac infarct patients remains unclear. However, emerging evidence points at possible epigenetic mechanisms of doxycycline that merit consideration from a therapeutic point of view. For instance, in models of abdominal aortic aneurysm, a vascular disease associated with the overexpression of MMP-2 [104], doxycycline concentration-dependently inhibited the secretion of MMP-2 in cultured human smooth muscle cells and abdominal aortic aneurysm explants [104], which was accompanied by a reduction in the half-life of $M M P 2 \mathrm{mRNA}$ from $49 \mathrm{~h}$ to $28 \mathrm{~h}$ [104]. A converging line of research indicates that the doxycycline inhibition of MMP-2 expression may involve post-transcriptional mRNA destabilization and downregulation of MMP2 gene expression in cultured human skin keratinocytes [105]. Further, doxycycline can also alter microRNA expression [108]. Regulatory T cells in mice treated with doxycycline showed increased expression of the miR-486 family of microRNA (miR-486-3p and miR-486-5p) after a fourweek recovery period following doxycycline treatment [108] with recent studies showing that the MMP2 and MMP9 mRNAs are targets of miR-486 [109-111]. In particular, induction of miR-486-5p suppressed MMP-2 and MMP-9 protein expression in human colorectal cancer cell lines [110] as well as in human lung adenocarcinoma cell lines [111], suggesting that an epigenetic mechanism by which doxycycline affects MMP expression occurs via the induction of miR-486. Doxycycline can indirectly impact MMP expression by altering microRNA/mRNA expression.

\section{Conclusions}

Various epigenetic mechanisms: DNA methylation, histone acetylation/methylation, and alterations in small non-coding RNAs can influence the expression of MMPs, tissue inhibitors of MMPs, and the transcription factors that regulate the expression of MMPs (Table 1). Highly prevalent diseases and commonly prescribed medicinal drugs can introduce epigenetic pressure through these mechanisms to alter the proteolytic activity of MMPs. Bacterial and viral infections also induce epigenetic pressure to directly or indirectly affect the expression of MMP genes. Interestingly, SARS-CoV2 infection induces genome-wide DNA methylation, affecting a multitude of genes, including MMP transcription factors, and is likely to directly or indirectly change the MMP gene expression of profile in infected host cells. Our understanding of (and our ability to effectively treat) human conditions associated with alterations in the proteolytic activity of MMPs must consider that these conditions and their medicinal treatments are potential causes of epigenetics-related alterations in MMP activity. Whether the epigenetic mechanisms affecting the activity of MMPs can be therapeutically targeted is unclear and warrants further research. Future research should have the goal of understanding and confirming the effects of the short- and long-term epigenetic pressures induced by MMP-associated pathologies and medicinal drugs on the expression of MMPs, endogenous MMP inhibitors, and MMP substrates. Although the effects of statins on the expression of MMPs are well documented, more research is needed to establish the involvement of specific epigenetic mechanisms. How epigenetic pressure induced by viral and bacterial infections affects MMP expression warrants determination through future research. The regulation of gene expression by miRNAs might open opportunities for the selective manipulation of MMP 
expression and signaling when pharmacological inhibitors are not available. The future of MMP biology appears to be as exciting and rewarding as ever.

Table 1. Examples of epigenetic mechanisms that regulate gene expression of MMPs and TIMPs.

\begin{tabular}{|c|c|c|}
\hline Target Gene & Epigenetic Control Mechanism & Reference \\
\hline MMP1 & $\begin{array}{l}\text { - } \quad \text { DNA methylation } \\
\text { - } \quad \text { histone acetylation and chromatin remodeling } \\
\text { H3 lysine-27-trimethylation }\end{array}$ & $\begin{array}{l}{[23,54]} \\
{[29,30,57]} \\
{[55]}\end{array}$ \\
\hline MMP2 & $\begin{array}{l}\text { - } \quad \text { DNA methylation of CpG sites and histone H3 lysine-27-trimethylation } \\
\text { - } \quad \text { Targeted by miR- } 488, \text { miR-206, miR-29b, miR-451, miR-486-5p } \\
\text { - } \quad \text { GRK6 promoter hypermethylation }\end{array}$ & $\begin{array}{l}{[35,36]} \\
{[22,45,109,110]} \\
{[41]}\end{array}$ \\
\hline$M M P 3$ & $\begin{array}{l}\text { - } \quad \text { DNA methylation by DNA methyltransferases (e.g., Dmt-1 and Dmt3b) } \\
\text { - } \quad \text { H3 lysine-27-trimethylation } \\
\text { histone acetylation and chromatin remodeling }\end{array}$ & $\begin{array}{l}{[25,49,50]} \\
{[55]} \\
{[57]}\end{array}$ \\
\hline MMP7 & - $\quad$ GRK6 promoter hypermethylation & [41] \\
\hline MMP9 & $\begin{array}{l}\text { - } \quad \text { DNA methylation at the } M M P 9 \text { promoter } \\
\text { - } \mathrm{H} 3 / \mathrm{H} 4 \text { acetylation } \\
\text { - } \mathrm{miR}-206, \mathrm{miR}-211, \mathrm{miR}-218, \mathrm{miR}-212 / 132, \mathrm{miR}-29 \mathrm{~b}, \mathrm{miR}-451, \mathrm{miR}-486-5 \mathrm{p} \\
\text { - } \mathrm{H} 3 \mathrm{~K} 4 \mathrm{me} 2 \text { and } \mathrm{H} 3 \mathrm{~K} 4 \mathrm{me} 3 \mathrm{methylation} \text { by SMYD3 } \\
\mathrm{H} 3 \text { lysine-27-trimethylation }\end{array}$ & $\begin{array}{l}{[24,47,49,50]} \\
{[28]} \\
{[22,43,110,111]} \\
{[37,42]} \\
{[55]}\end{array}$ \\
\hline MMP10 & $\begin{array}{l}\text { - } \quad \text { DNA methylation of promoter } \\
\text { - } \quad \text { histone acetylation and chromatin remodeling }\end{array}$ & $\begin{array}{l}{[25]} \\
{[29,30]}\end{array}$ \\
\hline MMP13 & $\begin{array}{l}\text { - } \quad \text { DNA methylation } \\
\text { - } \quad \text { HiR-143, miR-27b, miR-222 } \\
\text { - } \quad \text { histone acetylation/de-acetylation and chromatin remodeling }\end{array}$ & $\begin{array}{l}{[49,50]} \\
{[22,51,52]} \\
{[55]} \\
{[29,30,51]}\end{array}$ \\
\hline MMP14 & $\begin{array}{l}\text { - } \quad \text { DNA methylation of } \mathrm{CpG} \text { sites and histone H3 lysine-27-trimethylation } \\
\text { - miR-10b }\end{array}$ & $\begin{array}{l}{[35,36,54]} \\
{[22]}\end{array}$ \\
\hline MMP16 & - $\quad$ miR-146b & [22] \\
\hline TIMP2 & - DNA methylation of two CpG sites in the promoter & [35] \\
\hline TIMP3 & - $\quad \operatorname{miR}-181 b, \mathrm{miR}-221 / 222$ & [22] \\
\hline
\end{tabular}

Author Contributions: All authors contributed to writing and revision of the manuscript. All authors have read and agreed to the published version of the manuscript.

Funding: This research was funded by Natural Sciences and Engineering Council of Canada Discovery (grant number: RES0034250) and University of Alberta Hospital Foundation for Medical Research (grant number: RES0048483). APC has been waived.

Institutional Review Board Statement: Not applicable.

Informed Consent Statement: Not applicable.

Data Availability Statement: Not applicable.

Acknowledgments: H.S. was supported by an Alberta Graduate Excellence Scholarship. R.T. was supported by a Summer Research Scholarship from Alberta Innovates. The figure in this article was generated using biorender.com.

Conflicts of Interest: The authors declare no conflict of interest. 


\section{References}

1. Page-McCaw, A.; Ewald, A.J.; Werb, Z. Matrix metalloproteinases and the regulation of tissue remodelling. Nat. Rev. Mol. Cell Biol. 2007, 8, 221-233. [CrossRef]

2. Cook, R.N.; Sarker, H.; Fernandez-Patron, C. Pathologies of MMP-2 underactivity: A perspective on a neglected condition. Can. J. Physiol. Pharm. 2018, 97, 486-492. [CrossRef] [PubMed]

3. Felsenfeld, G. A brief history of epigenetics. Cold Spring Harb. Perspect. Biol. 2014, 6, a018200. [CrossRef]

4. Bednar, J.; Horowitz, R.A.; Grigoryev, S.A.; Carruthers, L.M.; Hansen, J.C.; Koster, A.J.; Woodcock, C.L. Nucleosomes, linker DNA, and linker histone form a unique structural motif that directs the higher-order folding and compaction of chromatin. Proc. Natl. Acad. Sci. USA 1998, 95, 14173-14178. [CrossRef] [PubMed]

5. Marino-Ramirez, L.; Kann, M.G.; Shoemaker, B.A.; Landsman, D. Histone structure and nucleosome stability. Expert. Rev. Proteom. 2005, 2, 719-729. [CrossRef] [PubMed]

6. Bannister, A.J.; Kouzarides, T. Regulation of chromatin by histone modifications. Cell Res 2011, 21, 381-395. [CrossRef] [PubMed]

7. Yang, Z.; Zheng, C.; Thiriet, C.; Hayes, J.J. The core histone N-terminal tail domains negatively regulate binding of transcription factor IIIA to a nucleosome containing a 5S RNA gene via a novel mechanism. Mol. Cell Biol. 2005, 25, 241-249. [CrossRef] [PubMed]

8. Lee, D.Y.; Hayes, J.J.; Pruss, D.; Wolffe, A.P. A positive role for histone acetylation in transcription factor access to nucleosomal DNA. Cell 1993, 72, 73-84. [CrossRef]

9. Egger, G.; Liang, G.; Aparicio, A.; Jones, P.A. Epigenetics in human disease and prospects for epigenetic therapy. Nature 2004, 429, 457-463. [CrossRef]

10. Robertson, K.D. DNA methylation and chromatin-Unraveling the tangled web. Oncogene 2002, 21, 5361-5379. [CrossRef]

11. Jenuwein, T.; Allis, C.D. Translating the histone code. Science 2001, 293, 1074-1080. [CrossRef]

12. Kooistra, S.M.; Helin, K. Molecular mechanisms and potential functions of histone demethylases. Nat. Rev. Mol. Cell Biol. 2012, 13, 297-311. [CrossRef]

13. Trievel, R.C. Structure and function of histone methyltransferases. Crit. Rev. Eukaryot. Gene Expr. 2004, 14, 147-169. [CrossRef] [PubMed]

14. Lam, J.K.; Chow, M.Y.; Zhang, Y.; Leung, S.W. siRNA Versus miRNA as Therapeutics for Gene Silencing. Mol. Nucleic Acids 2015, 4, e252. [CrossRef]

15. Vandooren, J.; Van den Steen, P.E.; Opdenakker, G. Biochemistry and molecular biology of gelatinase B or matrix metalloproteinase9 (MMP-9): The next decade. Crit. Rev. Biochem. Mol. Biol. 2013, 48, 222-272. [CrossRef]

16. Massaro, M.; Zampolli, A.; Scoditti, E.; Carluccio, M.A.; Storelli, C.; Distante, A.; De Caterina, R. Statins inhibit cyclooxygenase-2 and matrix metalloproteinase-9 in human endothelial cells: Anti-angiogenic actions possibly contributing to plaque stability. Cardiovasc. Res. 2010, 86, 311-320. [CrossRef]

17. Luan, Z.; Chase, A.J.; Newby, A.C. Statins inhibit secretion of metalloproteinases-1, -2, -3, and -9 from vascular smooth muscle cells and macrophages. Arter. Thromb. Vasc. Biol. 2003, 23, 769-775. [CrossRef] [PubMed]

18. Allen, S.C.; Mamotte, C.D.S. Pleiotropic and Adverse Effects of Statins-Do Epigenetics Play a Role? J. Pharm. Exp. 2017, 362, 319-326. [CrossRef] [PubMed]

19. Hanemaaijer, R.; Visser, H.; Koolwijk, P.; Sorsa, T.; Salo, T.; Golub, L.M.; van Hinsbergh, V.W. Inhibition of MMP synthesis by doxycycline and chemically modified tetracyclines (CMTs) in human endothelial cells. Adv. Dent. Res. 1998, 12, 114-118. [CrossRef] [PubMed]

20. Hardy, E.; Hardy-Sosa, A.; Fernandez-Patron, C. MMP-2: Is too low as bad as too high in the cardiovascular system? Am. J. Physiol. Heart Circ. Physiol. 2018, 315, H1332-H1340. [CrossRef]

21. Yan, C.; Boyd, D.D. Regulation of matrix metalloproteinase gene expression. J. Cell Physiol. 2007, 211, 19-26. [CrossRef]

22. Chernov, A.V.; Strongin, A.Y. Epigenetic regulation of matrix metalloproteinases and their collagen substrates in cancer. Biomol Concepts 2011, 2, 135-147. [CrossRef]

23. Wang, H.; Ogawa, M.; Wood, J.R.; Bartolomei, M.S.; Sammel, M.D.; Kusanovic, J.P.; Walsh, S.W.; Romero, R.; Strauss, J.F., 3rd. Genetic and epigenetic mechanisms combine to control MMP1 expression and its association with preterm premature rupture of membranes. Hum. Mol. Genet. 2008, 17, 1087-1096. [CrossRef]

24. Chicoine, E.; Esteve, P.O.; Robledo, O.; Van Themsche, C.; Potworowski, E.F.; St-Pierre, Y. Evidence for the role of promoter methylation in the regulation of MMP-9 gene expression. Biochem. Biophys. Res. Commun. 2002, 297, 765-772. [CrossRef]

25. Couillard, J.; Demers, M.; Lavoie, G.; St-Pierre, Y. The role of DNA hypomethylation in the control of stromelysin gene expression. Biochem. Biophys. Res. Commun. 2006, 342, 1233-1239. [CrossRef] [PubMed]

26. Berger, S.L. Histone modifications in transcriptional regulation. Curr. Opin. Genet. Dev. 2002, 12, 142-148. [CrossRef]

27. Sudarsanam, P.; Winston, F. The Swi/Snf family nucleosome-remodeling complexes and transcriptional control. Trends Genet. 2000, 16, 345-351. [CrossRef]

28. Yan, C.; Wang, H.; Toh, Y.; Boyd, D.D. Repression of 92-kDa type IV collagenase expression by MTA1 is mediated through direct interactions with the promoter via a mechanism, which is both dependent on and independent of histone deacetylation. J. Biol. Chem. 2003, 278, 2309-2316. [CrossRef] [PubMed]

29. Chang, S.; Young, B.D.; Li, S.; Qi, X.; Richardson, J.A.; Olson, E.N. Histone deacetylase 7 maintains vascular integrity by repressing matrix metalloproteinase 10. Cell 2006, 126, 321-334. [CrossRef] [PubMed] 
30. Young, D.A.; Lakey, R.L.; Pennington, C.J.; Jones, D.; Kevorkian, L.; Edwards, D.R.; Cawston, T.E.; Clark, I.M. Histone deacetylase inhibitors modulate metalloproteinase gene expression in chondrocytes and block cartilage resorption. Arthritis. Res. 2005, 7, R503-R512. [CrossRef] [PubMed]

31. Yu, Q.; Stamenkovic, I. Cell surface-localized matrix metalloproteinase-9 proteolytically activates TGF-beta and promotes tumor invasion and angiogenesis. Genes Dev. 2000, 14, 163-176.

32. Mitsiades, N.; Yu, W.H.; Poulaki, V.; Tsokos, M.; Stamenkovic, I. Matrix metalloproteinase-7-mediated cleavage of Fas ligand protects tumor cells from chemotherapeutic drug cytotoxicity. Cancer Res. 2001, 61, 577-581. [PubMed]

33. Bergers, G.; Brekken, R.; McMahon, G.; Vu, T.H.; Itoh, T.; Tamaki, K.; Tanzawa, K.; Thorpe, P.; Itohara, S.; Werb, Z.; et al. Matrix metalloproteinase-9 triggers the angiogenic switch during carcinogenesis. Nat. Cell Biol. 2000, 2, 737-744. [CrossRef] [PubMed]

34. Boire, A.; Covic, L.; Agarwal, A.; Jacques, S.; Sherifi, S.; Kuliopulos, A. PAR1 is a matrix metalloprotease-1 receptor that promotes invasion and tumorigenesis of breast cancer cells. Cell 2005, 120, 303-313. [CrossRef] [PubMed]

35. Chernov, A.V.; Sounni, N.E.; Remacle, A.G.; Strongin, A.Y. Epigenetic control of the invasion-promoting MT1-MMP/MMP2/TIMP-2 axis in cancer cells. J. Biol. Chem. 2009, 284, 12727-12734. [CrossRef]

36. Sato, N.; Maehara, N.; Su, G.H.; Goggins, M. Effects of 5-aza-2'-deoxycytidine on matrix metalloproteinase expression and pancreatic cancer cell invasiveness. J. Natl. Cancer Inst. 2003, 95, 327-330. [CrossRef]

37. Klassen, L.M.B.; Chequin, A.; Manica, G.C.M.; Biembengut, I.V.; Toledo, M.B.; Baura, V.A.; de, O.P.F.; Ramos, E.A.S.; Costa, F.F.; de Souza, E.M.; et al. MMP9 gene expression regulation by intragenic epigenetic modifications in breast cancer. Gene 2018, 642, 461-466. [CrossRef]

38. Brockmeyer, P.; Hemmerlein, B. Epigenetic modification suppresses proliferation, migration and invasion of urothelial cancer cell lines. Oncol. Lett. 2016, 12, 1693-1700. [CrossRef]

39. Wang, S.; Wu, W.; Claret, F.X. Mutual regulation of microRNAs and DNA methylation in human cancers. Epigenetics 2017, 12, 187-197. [CrossRef] [PubMed]

40. Raghuwanshi, S.K.; Smith, N.; Rivers, E.J.; Thomas, A.J.; Sutton, N.; Hu, Y.; Mukhopadhyay, S.; Chen, X.L.; Leung, T.; Richardson, R.M. G protein-coupled receptor kinase 6 deficiency promotes angiogenesis, tumor progression, and metastasis. J. Immunol. 2013, 190, 5329-5336. [CrossRef] [PubMed]

41. Yao, S.; Wu, D.; Chen, J.; Wang, P.; Lv, X.; Huang, J. Hypermethylation of the G protein-coupled receptor kinase 6 (GRK6) promoter inhibits binding of C/EBPalpha, and GRK6 knockdown promotes cell migration and invasion in lung adenocarcinoma cells. FEBS Open Bio 2019, 9, 605-617. [CrossRef] [PubMed]

42. Cock-Rada, A.M.; Medjkane, S.; Janski, N.; Yousfi, N.; Perichon, M.; Chaussepied, M.; Chluba, J.; Langsley, G.; Weitzman, J.B. SMYD3 promotes cancer invasion by epigenetic upregulation of the metalloproteinase MMP-9. Cancer Res. 2012, 72, 810-820. [CrossRef] [PubMed]

43. Asuthkar, S.; Velpula, K.K.; Chetty, C.; Gorantla, B.; Rao, J.S. Epigenetic regulation of miRNA-211 by MMP-9 governs glioma cell apoptosis, chemosensitivity and radiosensitivity. Oncotarget 2012, 3, 1439-1454. [CrossRef] [PubMed]

44. Liu, P.; Sun, M.; Sader, S. Matrix metalloproteinases in cardiovascular disease. Can. J. Cardiol. 2006, 22 (Suppl. B), 25B-30B. [CrossRef]

45. Chen, K.C.; Wang, Y.S.; Hu, C.Y.; Chang, W.C.; Liao, Y.C.; Dai, C.Y.; Juo, S.H. OxLDL up-regulates microRNA-29b, leading to epigenetic modifications of MMP-2/MMP-9 genes: A novel mechanism for cardiovascular diseases. FASEB J. 2011, 25, 1718-1728. [CrossRef]

46. Newby, A.C. Matrix metalloproteinases regulate migration, proliferation, and death of vascular smooth muscle cells by degrading matrix and non-matrix substrates. Cardiovasc. Res. 2006, 69, 614-624. [CrossRef]

47. Kuo, H.C.; Li, S.C.; Huang, L.H.; Huang, Y.H. Epigenetic hypomethylation and upregulation of matrix metalloproteinase 9 in Kawasaki disease. Oncotarget 2017, 8, 60875-60891. [CrossRef]

48. Hardy, E.; Fernandez-Patron, C. Destroy to Rebuild: The Connection Between Bone Tissue Remodeling and Matrix Metalloproteinases. Front Physiol. 2020, 11, 47. [CrossRef]

49. Fernandez-Tajes, J.; Soto-Hermida, A.; Vazquez-Mosquera, M.E.; Cortes-Pereira, E.; Mosquera, A.; Fernandez-Moreno, M.; Oreiro, N.; Fernandez-Lopez, C.; Fernandez, J.L.; Rego-Perez, I.; et al. Genome-wide DNA methylation analysis of articular chondrocytes reveals a cluster of osteoarthritic patients. Ann. Rheum. Dis. 2014, 73, 668-677. [CrossRef]

50. Roach, H.I.; Yamada, N.; Cheung, K.S.; Tilley, S.; Clarke, N.M.; Oreffo, R.O.; Kokubun, S.; Bronner, F. Association between the abnormal expression of matrix-degrading enzymes by human osteoarthritic chondrocytes and demethylation of specific $\mathrm{CpG}$ sites in the promoter regions. Arthritis. Rheum. 2005, 52, 3110-3124. [CrossRef]

51. Song, J.; Jin, E.H.; Kim, D.; Kim, K.Y.; Chun, C.H.; Jin, E.J. MicroRNA-222 regulates MMP-13 via targeting HDAC-4 during osteoarthritis pathogenesis. BBA Clin. 2015, 3, 79-89. [CrossRef] [PubMed]

52. Akhtar, N.; Rasheed, Z.; Ramamurthy, S.; Anbazhagan, A.N.; Voss, F.R.; Haqqi, T.M. MicroRNA-27b regulates the expression of matrix metalloproteinase 13 in human osteoarthritis chondrocytes. Arthritis Rheum. 2010, 62, 1361-1371. [CrossRef]

53. Araki, Y.; Mimura, T. Matrix Metalloproteinase Gene Activation Resulting from Disordred Epigenetic Mechanisms in Rheumatoid Arthritis. Int. J. Mol. Sci. 2017, 18, 905. [CrossRef] [PubMed]

54. Karouzakis, E.; Gay, R.E.; Michel, B.A.; Gay, S.; Neidhart, M. DNA hypomethylation in rheumatoid arthritis synovial fibroblasts. Arthritis Rheum. 2009, 60, 3613-3622. [CrossRef] 
55. Araki, Y.; Tsuzuki Wada, T.; Aizaki, Y.; Sato, K.; Yokota, K.; Fujimoto, K.; Kim, Y.T.; Oda, H.; Kurokawa, R.; Mimura, T. Histone Methylation and STAT-3 Differentially Regulate Interleukin-6-Induced Matrix Metalloproteinase Gene Activation in Rheumatoid Arthritis Synovial Fibroblasts. Arthritis Rheumatol. 2016, 68, 1111-1123. [PubMed]

56. Wang, X.; Tang, K.; Wang, Y.; Chen, Y.; Yang, M.; Gu, C.; Wang, J.; Yuan, Y. Elevated microRNA1455p increases matrix metalloproteinase9 by activating the nuclear factorkappaB pathway in rheumatoid arthritis. Mol. Med. Rep. 2019, 20, $2703-2711$. [PubMed]

57. Moores, R.C.; Brilha, S.; Schutgens, F.; Elkington, P.T.; Friedland, J.S. Epigenetic Regulation of Matrix Metalloproteinase-1 and -3 Expression in Mycobacterium tuberculosis Infection. Front. Immunol. 2017, 8, 602. [CrossRef]

58. Elkington, P.; Shiomi, T.; Breen, R.; Nuttall, R.K.; Ugarte-Gil, C.A.; Walker, N.F.; Saraiva, L.; Pedersen, B.; Mauri, F.; Lipman, M.; et al. MMP-1 drives immunopathology in human tuberculosis and transgenic mice. J. Clin. Investig. 2011, 121, 1827-1833. [CrossRef]

59. Al Shammari, B.; Shiomi, T.; Tezera, L.; Bielecka, M.K.; Workman, V.; Sathyamoorthy, T.; Mauri, F.; Jayasinghe, S.N.; Robertson, B.D.; D'Armiento, J.; et al. The Extracellular Matrix Regulates Granuloma Necrosis in Tuberculosis. J. Infect. Dis. 2015, 212, 463-473. [CrossRef]

60. Green, J.A.; Elkington, P.T.; Pennington, C.J.; Roncaroli, F.; Dholakia, S.; Moores, R.C.; Bullen, A.; Porter, J.C.; Agranoff, D.; Edwards, D.R.; et al. Mycobacterium tuberculosis upregulates microglial matrix metalloproteinase- 1 and -3 expression and secretion via NF-kappaB- and Activator Protein-1-dependent monocyte networks. J. Immunol. 2010, 184, 6492-6503. [CrossRef]

61. Choudhary, C.; Kumar, C.; Gnad, F.; Nielsen, M.L.; Rehman, M.; Walther, T.C.; Olsen, J.V.; Mann, M. Lysine acetylation targets protein complexes and co-regulates major cellular functions. Science 2009, 325, 834-840. [CrossRef] [PubMed]

62. Michael, L.F.; Asahara, H.; Shulman, A.I.; Kraus, W.L.; Montminy, M. The phosphorylation status of a cyclic AMP-responsive activator is modulated via a chromatin-dependent mechanism. Mol. Cell Biol. 2000, 20, 1596-1603. [CrossRef] [PubMed]

63. Moser, M.A.; Hagelkruys, A.; Seiser, C. Transcription and beyond: The role of mammalian class I lysine deacetylases. Chromosoma 2014, 123, 67-78. [CrossRef] [PubMed]

64. Barchowsky, A.; Frleta, D.; Vincenti, M.P. Integration of the NF-kappaB and mitogen-activated protein kinase/AP-1 pathways at the collagenase-1 promoter: Divergence of IL-1 and TNF-dependent signal transduction in rabbit primary synovial fibroblasts. Cytokine 2000, 12, 1469-1479. [CrossRef]

65. Oh, J.; Takahashi, R.; Kondo, S.; Mizoguchi, A.; Adachi, E.; Sasahara, R.M.; Nishimura, S.; Imamura, Y.; Kitayama, H.; Alexander, D.B.; et al. The membrane-anchored MMP inhibitor RECK is a key regulator of extracellular matrix integrity and angiogenesis. Cell 2001, 107, 789-800. [CrossRef]

66. Liu, L.T.; Chang, H.C.; Chiang, L.C.; Hung, W.C. Histone deacetylase inhibitor up-regulates RECK to inhibit MMP-2 activation and cancer cell invasion. Cancer Res 2003, 63, 3069-3072.

67. Garrington, T.P.; Johnson, G.L. Organization and regulation of mitogen-activated protein kinase signaling pathways. Curr. Opin. Cell Biol. 1999, 11, 211-218. [CrossRef]

68. Vincenti, M.P.; Brinckerhoff, C.E. Transcriptional regulation of collagenase (MMP-1, MMP-13) genes in arthritis: Integration of complex signaling pathways for the recruitment of gene-specific transcription factors. Arthritis Res. 2002, 4, 157-164. [CrossRef]

69. Ashburner, B.P.; Westerheide, S.D.; Baldwin, A.S., Jr. The p65 (RelA) subunit of NF-kappaB interacts with the histone deacetylase (HDAC) corepressors HDAC1 and HDAC2 to negatively regulate gene expression. Mol. Cell Biol. 2001, 21, 7065-7077. [CrossRef]

70. Mittelstadt, M.L.; Patel, R.C. AP-1 mediated transcriptional repression of matrix metalloproteinase-9 by recruitment of histone deacetylase 1 in response to interferon beta. PLoS ONE 2012, 7, e42152. [CrossRef]

71. Ram, M.; Sherer, Y.; Shoenfeld, Y. Matrix metalloproteinase-9 and autoimmune diseases. J Clin Immunol 2006, 26, 299-307. [CrossRef]

72. Galewska, Z.; Romanowicz, L.; Jaworski, S.; Bankowski, E. Gelatinase matrix metalloproteinase (MMP)-2 and MMP-9 of the umbilical cord blood in preeclampsia. Clin. Chem. Lab. Med. 2008, 46, 517-522. [CrossRef] [PubMed]

73. Elkington, P.T.; O'Kane, C.M.; Friedland, J.S. The paradox of matrix metalloproteinases in infectious disease. Clin. Exp. Immunol. 2005, 142, 12-20. [CrossRef] [PubMed]

74. Pagenstecher, A.; Stalder, A.K.; Kincaid, C.L.; Volk, B.; Campbell, I.L. Regulation of matrix metalloproteinases and their inhibitor genes in lipopolysaccharide-induced endotoxemia in mice. Am. J. Pathol. 2000, 157, 197-210. [CrossRef]

75. Aung, H.T.; Schroder, K.; Himes, S.R.; Brion, K.; van Zuylen, W.; Trieu, A.; Suzuki, H.; Hayashizaki, Y.; Hume, D.A.; Sweet, M.J.; et al. LPS regulates proinflammatory gene expression in macrophages by altering histone deacetylase expression. FASEB J. 2006, 20, 1315-1327. [CrossRef]

76. Seo, Y.L.; Heo, S.; Jang, K.L. Hepatitis C virus core protein overcomes H2O2-induced apoptosis by downregulating p14 expression via DNA methylation. J. Gen. Virol. 2015, 96 Pt 4, 822-832. [CrossRef]

77. Menachery, V.D.; Eisfeld, A.J.; Schafer, A.; Josset, L.; Sims, A.C.; Proll, S.; Fan, S.; Li, C.; Neumann, G.; Tilton, S.C.; et al. Pathogenic influenza viruses and coronaviruses utilize similar and contrasting approaches to control interferon-stimulated gene responses. mBio 2014, 5, e01174-14. [CrossRef]

78. Menachery, V.D.; Schafer, A.; Burnum-Johnson, K.E.; Mitchell, H.D.; Eisfeld, A.J.; Walters, K.B.; Nicora, C.D.; Purvine, S.O.; Casey, C.P.; Monroe, M.E.; et al. MERS-CoV and H5N1 influenza virus antagonize antigen presentation by altering the epigenetic landscape. Proc. Natl. Acad. Sci. USA 2018, 115, E1012-E1021. [CrossRef] [PubMed] 
79. Atlante, S.; Mongelli, A.; Barbi, V.; Martelli, F.; Farsetti, A.; Gaetano, C. The epigenetic implication in coronavirus infection and therapy. Clin. Epigenetics 2020, 12, 156. [CrossRef]

80. Hoffmann, M.; Kleine-Weber, H.; Schroeder, S.; Kruger, N.; Herrler, T.; Erichsen, S.; Schiergens, T.S.; Herrler, G.; Wu, N.H.; Nitsche, A.; et al. SARS-CoV-2 Cell Entry Depends on ACE2 and TMPRSS2 and Is Blocked by a Clinically Proven Protease Inhibitor. Cell 2020, 181, 271-280.e8. [CrossRef]

81. Sawalha, A.H.; Zhao, M.; Coit, P.; Lu, Q. Epigenetic dysregulation of ACE2 and interferon-regulated genes might suggest increased COVID-19 susceptibility and severity in lupus patients. medRxiv 2020, 108410. [CrossRef] [PubMed]

82. Corley, M.J.; Pang, A.P.S.; Dody, K.; Mudd, P.A.; Patterson, B.K.; Seethamraju, H.; Bram, Y.; Peluso, M.J.; Torres, L.; Iyer, N.S.; et al. Genome-wide DNA methylation profiling of peripheral blood reveals an epigenetic signature associated with severe COVID-19. J. Leukoc. Biol. 2021, e5HI0720-466R. [CrossRef]

83. Ueland, T.; Holter, J.C.; Holten, A.R.; Muller, K.E.; Lind, A.; Bekken, G.K.; Dudman, S.; Aukrust, P.; Dyrhol-Riise, A.M.; Heggelund, L. Distinct and early increase in circulating MMP-9 in COVID-19 patients with respiratory failure. J. Infect. 2020, 81, e41-e43. [CrossRef]

84. Elkington, P.T.; Friedland, J.S. Matrix metalloproteinases in destructive pulmonary pathology. Thorax 2006, 61, 259-266. [CrossRef] [PubMed]

85. O'Kane, C.M.; McKeown, S.W.; Perkins, G.D.; Bassford, C.R.; Gao, F.; Thickett, D.R.; McAuley, D.F. Salbutamol up-regulates matrix metalloproteinase-9 in the alveolar space in the acute respiratory distress syndrome. Crit. Care Med. 2009, 37, 2242-2249. [CrossRef] [PubMed]

86. Cox, D.J.; Coleman, A.M.; Gogan, K.M.; Phelan, J.J.; Cilian, O.M.; Dunne, P.J.; Basdeo, S.A.; Keane, J. Inhibiting Histone Deacetylases in Human Macrophages Promotes Glycolysis, IL-1beta, and T Helper Cell Responses to Mycobacterium tuberculosis. Front Immunol. 2020, 11, 1609. [CrossRef] [PubMed]

87. Guo, F.; Zhang, H.; McNair, N.N.; Mead, J.R.; Zhu, G. The Existing Drug Vorinostat as a New Lead Against Cryptosporidiosis by Targeting the Parasite Histone Deacetylases. J. Infect. Dis. 2018, 217, 1110-1117. [CrossRef]

88. Wang, X.; Song, Y.; Jacobi, J.L.; Tuan, R.S. Inhibition of histone deacetylases antagonized FGF2 and IL-1beta effects on MMP expression in human articular chondrocytes. Growth Factors 2009, 27, 40-49. [CrossRef]

89. Ateia, I.M.; Sutthiboonyapan, P.; Kamarajan, P.; Jin, T.; Godovikova, V.; Kapila, Y.L.; Fenno, J.C. Treponema denticola increases MMP-2 expression and activation in the periodontium via reversible DNA and histone modifications. Cell Microbiol. 2018, 20, e12815. [CrossRef]

90. Adhyaru, B.B.; Jacobson, T.A. Safety and efficacy of statin therapy. Nat. Rev. Cardiol. 2018, 15, 757-769. [CrossRef] [PubMed]

91. Ishikawa, S.; Hayashi, H.; Kinoshita, K.; Abe, M.; Kuroki, H.; Tokunaga, R.; Tomiyasu, S.; Tanaka, H.; Sugita, H.; Arita, T.; et al. Statins inhibit tumor progression via an enhancer of zeste homolog 2-mediated epigenetic alteration in colorectal cancer. Int. J. Cancer 2014, 135, 2528-2536. [CrossRef] [PubMed]

92. Karlic, H.; Thaler, R.; Gerner, C.; Grunt, T.; Proestling, K.; Haider, F.; Varga, F. Inhibition of the mevalonate pathway affects epigenetic regulation in cancer cells. Cancer Genet. 2015, 208, 241-252. [CrossRef] [PubMed]

93. Feig, J.E.; Shang, Y.; Rotllan, N.; Vengrenyuk, Y.; Wu, C.; Shamir, R.; Torra, I.P.; Fernandez-Hernando, C.; Fisher, E.A.; Garabedian, M.J. Statins promote the regression of atherosclerosis via activation of the CCR7-dependent emigration pathway in macrophages. PLoS ONE 2011, 6, e28534. [CrossRef] [PubMed]

94. Lin, Y.C.; Lin, J.H.; Chou, C.W.; Chang, Y.F.; Yeh, S.H.; Chen, C.C. Statins increase p21 through inhibition of histone deacetylase activity and release of promoter-associated HDAC1/2. Cancer Res. 2008, 68, 2375-2383. [CrossRef]

95. Marks, P.A. Histone deacetylase inhibitors: A chemical genetics approach to understanding cellular functions. Biochim Biophys. Acta 2010, 1799, 717-725. [CrossRef] [PubMed]

96. Marks, P.A.; Xu, W.S. Histone deacetylase inhibitors: Potential in cancer therapy. J. Cell Biochem. 2009, 107, 600-608. [CrossRef]

97. Li, H.; Rauch, T.; Chen, Z.X.; Szabo, P.E.; Riggs, A.D.; Pfeifer, G.P. The histone methyltransferase SETDB1 and the DNA methyltransferase DNMT3A interact directly and localize to promoters silenced in cancer cells. J. Biol. Chem. 2006, 281, 19489-19500. [CrossRef]

98. Kamio, K.; Liu, X.D.; Sugiura, H.; Togo, S.; Kawasaki, S.; Wang, X.; Ahn, Y.; Hogaboam, C.; Rennard, S.I. Statins inhibit matrix metalloproteinase release from human lung fibroblasts. Eur. Respir. J. 2010, 35, 637-646. [CrossRef]

99. Ikeda, U.; Shimpo, M.; Ohki, R.; Inaba, H.; Takahashi, M.; Yamamoto, K.; Shimada, K. Fluvastatin inhibits matrix metalloproteinase-1 expression in human vascular endothelial cells. Hypertension 2000, 36, 325-329. [CrossRef]

100. Bellosta, S.; Via, D.; Canavesi, M.; Pfister, P.; Fumagalli, R.; Paoletti, R.; Bernini, F. HMG-CoA reductase inhibitors reduce MMP-9 secretion by macrophages. Arter. Thromb. Vasc. Biol. 1998, 18, 1671-1678. [CrossRef]

101. Kim, S.E.; Thanh Thuy, T.T.; Lee, J.H.; Ro, J.Y.; Bae, Y.A.; Kong, Y.; Ahn, J.Y.; Lee, D.S.; Oh, Y.M.; Lee, S.D.; et al. Simvastatin inhibits induction of matrix metalloproteinase-9 in rat alveolar macrophages exposed to cigarette smoke extract. Exp. Mol. Med. 2009, 41, 277-287. [CrossRef]

102. Golub, L.M.; Ramamurthy, N.S.; McNamara, T.F.; Greenwald, R.A.; Rifkin, B.R. Tetracyclines inhibit connective tissue breakdown: New therapeutic implications for an old family of drugs. Crit. Rev. Oral Biol. Med. 1991, 2, 297-321. [CrossRef]

103. Jonat, C.; Chung, F.Z.; Baragi, V.M. Transcriptional downregulation of stromelysin by tetracycline. J. Cell Biochem. 1996, 60, 341-347. [CrossRef] 
104. Liu, J.; Xiong, W.; Baca-Regen, L.; Nagase, H.; Baxter, B.T. Mechanism of inhibition of matrix metalloproteinase-2 expression by doxycycline in human aortic smooth muscle cells. J. Vasc. Surg. 2003, 38, 1376-1383. [CrossRef]

105. Uitto, V.J.; Firth, J.D.; Nip, L.; Golub, L.M. Doxycycline and chemically modified tetracyclines inhibit gelatinase A (MMP-2) gene expression in human skin keratinocytes. Ann. N. Y. Acad. Sci. 1994, 732, 140-151. [CrossRef] [PubMed]

106. Zucker, S.; Cao, J.; Chen, W.T. Critical appraisal of the use of matrix metalloproteinase inhibitors in cancer treatment. Oncogene 2000, 19, 6642-6650. [CrossRef] [PubMed]

107. Cerisano, G.; Buonamici, P.; Valenti, R.; Sciagra, R.; Raspanti, S.; Santini, A.; Carrabba, N.; Dovellini, E.V.; Romito, R.; Pupi, A.; et al. Early short-term doxycycline therapy in patients with acute myocardial infarction and left ventricular dysfunction to prevent the ominous progression to adverse remodelling: The TIPTOP trial. Eur. Heart J. 2014, 35, 184-191. [CrossRef] [PubMed]

108. Becker, E.; Bengs, S.; Aluri, S.; Opitz, L.; Atrott, K.; Stanzel, C.; Castro, P.A.R.; Rogler, G.; Frey-Wagner, I. Doxycycline, metronidazole and isotretinoin: Do they modify microRNA/mRNA expression profiles and function in murine T-cells? Sci. Rep. 2016, 6, 37082. [CrossRef] [PubMed]

109. Liu, S.S.; Maguire, E.M.; Bai, Y.S.; Huang, L.; Liu, Y.; Xu, L.; Fauzi, I.; Zhang, S.Q.; Xiao, Q.; Ma, N.F. A Novel Regulatory Axis, CHD1L-MicroRNA 486-Matrix Metalloproteinase 2, Controls Spermatogonial Stem Cell Properties. Mol. Cell Biol. 2019, 39, e00357-18. [CrossRef] [PubMed]

110. Zhang, Y.; Fu, J.; Zhang, Z.; Qin, H. miR-486-5p regulates the migration and invasion of colorectal cancer cells through targeting PIK3R1. Oncol. Lett. 2018, 15, 7243-7248. [CrossRef]

111. Hu, H.; Xu, H.; Lu, F.; Zhang, J.; Xu, L.; Xu, S.; Jiang, H.; Zeng, Q.; Chen, E.; He, Z. Exosome-Derived miR-486-5p Regulates Cell Cycle, Proliferation and Metastasis in Lung Adenocarcinoma via Targeting NEK2. Front. Bioeng. Biotechnol. 2020, 8, 259. [CrossRef] [PubMed] 